\title{
Human development and convergence among the states of former Yugoslavia
}

\author{
IVAN VUJAČIĆ ${ }^{1 *}$ @ , JELICA PETROVIĆ-VUJAČIĆ ${ }^{2}$ (D) \\ SVETOZAR TANASKOVIĆ ${ }^{1}$ (D) and MARKO MILJKOVIĆ ${ }^{2}$
}

\author{
${ }^{1}$ Faculty of Economics, University of Belgrade, Kamenička 6, Beograd, 11000, Serbia \\ ${ }^{2}$ Faculty of Transport and Traffic Engineering, University of Belgrade, Beograd, Serbia
}

Received: November 12, 2018 • Revised manuscript received: April 26, 2019 • Accepted: June 15, 2019

(C 2020 Akadémiai Kiadó, Budapest

\begin{abstract}
After the devastation of the Second World War, the federal units of the former Yugoslavia were on their way to catching up with the Western Europe, with different degrees of success. In fact, Yugoslavia was considered a success story among the socialist economies due to its specific self-management system. Nevertheless, among the Federal units that later became independent states, regional differences in development level increased, in spite of the proclaimed policy to narrow them. Enough time has passed since the wars of the breakup and the economic transition to check if this divergence is continuing under a capitalist market system, now that all the countries are on the path to the European Union (EU) accession. The paper tests the convergence hypothesis among the states of the former Yugoslavia in terms of Human Development Index (HDI), as a more complex indicator of country development than GDP per capita. The results of two different approaches to test for the presence of $\beta$ (beta) and $\sigma$ (sigma) convergence suggest that the gap between the states of former Yugoslavia is closing, albeit at a slow rate. Given that convergence is slow, the active EU policies aimed at hastening the accession of the currently non-member states of the former Yugoslavia would accelerate the process.
\end{abstract}

\section{KEYWORDS}

human development index, economic growth, convergence, Yugoslavia, Western Balkans

JEL CLASSIFICATION INDICES

010, 015, 052, 057, P20

*Corresponding author. E-mail: ivujacic@ekof.bg.ac.rs 


\section{INTRODUCTION}

The European Union (EU) is the only region in the world in which, over a long period of time, the lower-income countries have experienced both higher real GDP and higher real GDP per capita growth rates than the higher income countries. This has led to a significant convergence of GDP per capita, as a general measure of standard of living, bringing lower income countries closer to their richer neighbours (Gill-Raiser 2012: 4). It should therefore not come as a surprise that as they approached full membership, the new EU member states expected to replicate this experience through the series of reforms required by the accession process. In fact, the promise of catching up was one of the major reasons for them embarking on the path to membership in the first place. The states that were formed in the territory of the former Yugoslavia had similar aspirations and expectations. Slovenia and Croatia became the full members in 2004 and 2013 respectively, while the others are in various stages of the accession process. Convergence has been a political issue and a source of legitimacy ever since the rise of the "Third World." However, nowhere it is a more urgent issue than in the European periphery and among the latecomers to membership. After all, it is one of the sources of the legitimacy of accession, as well as the legitimacy of the EU itself.

High income disparity and a widening gap between the regions have often been underlined as the determining factors in the breakup of Yugoslavia. Under such circumstances, preserving political and economic integration was rightly seen as extremely difficult. This paper gives a short historical overview of the economic development of Yugoslavia before and after its breakup and the disparities in the levels of development of the states formed in its territory. The paper concentrates on the existence and the speed of convergence between the states formed from the federal units of Yugoslavia. The period chosen to test convergence is the immediate past. This choice was made because it provides enough distance from the end of the wars and the varying consequences of those conflicts, and also provides enough time for immediate reconstruction and embarking on the transition process. Furthermore, the declared intent of the states has been full EU membership. Since the accession process requires reforms that take time, the choice of this period should allow comparison of the effect of these reforms in the less developed states that are catching-up, with the level of development in the states that have been more successful in converging with the EU (Slovenia). In other words, the existence of convergence should be linked to the success of transition and the institutional reforms that bring these states closer to the EU.

The existence of convergence also sheds light on whether market economies generate results that lead to the narrowing of development gaps, as opposed to the system of a self-managed market socialist economy as existed in Yugoslavia, which failed to do so in spite of declaring this as a goal and applying the appropriate policies. The major feature of the market-oriented selfmanagement system was that - at least on paper - state-owned enterprises were run by the workers' councils with decision-making powers regarding strategic decisions and the appointment of management (Matuszak - Szarzec 2019). Thus, enterprises were entrusted with managing their own public property (or "social property," constitutionally defined as belonging to society as a whole rather than to the state), short of the right of disposing it. We use the Human Development Index (HDI) as a measure of development level because it includes dimensions not taken into account by GDP per capita, as discussed later. Finally, the results are discussed and 
suggestions for possible further research are outlined, along with the possible policy implications.

\section{A HISTORICAL OVERVIEW OF YUGOSLAVIA'S ECONOMIC GROWTH 1945-1990}

\subsection{Yugoslavia - formation, socialism, and self-management}

In terms of the development level, Yugoslavia, a country formed in 1918 that broke up in 1991 through armed conflicts, was heterogeneous from the very beginning. This difficult unification of "Yugoslav" people of 1918 was followed by the Great Depression, the rise of Fascism, and the approaching threat from Nazi Germany, which all added to the internal strife and impeded economic development. The devastation and huge loss of life resulting from the Second World War (WWII) left the country in a dire economic situation in 1945.

The unification of the "Yugoslav" people (South Slavs) in the aftermath of WWI was extremely stressful. Any analysis of Yugoslavia's long-term development has to take into account that the historical experience of Slovenia and Croatia, which were under the Hapsburg rule till 1918 , is very different from that of the other regions, which were under the Ottoman rule until semi-independent or fully independent states were created in the $19^{\text {th }}$ century. It can be argued that the effect of this radically different historical background has lasted right up to the current period, and that culture in the broadest sense has played a crucial role in maintaining and further deepening the huge divide between these regions and the rest of Yugoslavia. Others has pointed to institutional reasons for the lack of development in the Ottoman-held Balkans during the period before WWI (Palairet 1997), implying long-term consequences. These questions regarding initial conditions are pertinent when comparing economic systems and their transformation (Gregory - Stuart 2014). Nevertheless, these initial conditions may not be so strong: Croatia and Slovenia shared the same initial conditions but with very different results, as shown by Croatia's less-than-impressive growth rates. Similarly, Montenegro, one of the less developed countries, has shown better results than others with similar historical backgrounds.

This paper will not focus on the period before WWII, as we consider the effects of Yugoslavia's common political and economic system in the more recent past - which lasted for almost half a century - as more important for the understanding of the current developments. Yugoslavia was not only reunited after WWII but it was also unified under a common communist ideology, which evolved into a unique economic system. After the split with the Soviet bloc in 1948 there was a huge drop in growth rates due to:

- the severance of economic ties with the USSR and the Eastern European countries,

- a failed attempt at agricultural collectivisation (starting in 1949) that had to be abandoned, and

- bad harvests which almost led to starvation in a still largely agricultural country.

Needless to say, this affected the average growth rate of the period.

Given that the Cold War was at its height, significant foreign aid, mostly from the United States, was made available to the Yugoslav Government after the Tito - Stalin split. Aid was later substituted by foreign soft loans, a significant portion coming from the World Bank (from the 
early 1960s) - a product of the "political entrepreneurship" of the Yugoslav political elite and which should not affect the evaluation of the country's economic performance.

After splitting with the Soviet Union in 1948 there was also a slow evolution to a socialist market economy, its essential trait being the already described unique model of self-management. The period that followed the introduction of self-management was the period of highest growth rates in the post war period till 1964. The self-management system inspired a broad theoretical literature on labour-managed firms (Ward 1958; Vanek 1970), as well as theoretical and empirical analyses of the functioning of the system as a whole (Horvat 1982; Estrin 1983, Bajt 1988). At the macroeconomic level of coordination, market institutions were formed (e.g., commercial banks, chambers of commerce), similar to those in other market economies.

Recognising that limited decentralisation of investment decisions was putting limits on economic growth, a broad market economy-oriented reform was inaugurated in 1965. As central planning was dismantled there was also a process of decentralisation that empowered the Yugoslav republics by giving them significant and relative economic autonomy in relation to the federal government. These features made Yugoslavia unique among the communist countries. The liberalisation and market-oriented approach went hand in hand with greater freedoms, one of the most important being the right to move abroad, which in the mid-1960s led to mass emigration of "guest workers," mostly to Western Europe. As a consequence, and unlike in any other communist country, remittances began to play a role in the Yugoslav economy.

The controversy over the decentralisation of control of investment led to the creation of regional banks and further decentralization in 1974 (when a new constitution was adopted) that in many respects gave a confederate character to the now loose Yugoslav federation. The empowerment of the regional communist party elites further stifled market reforms transforming the economic system into a "contractual" economy (Lampe 2000), where credit control was given back to party hierarchies at the regional and local level through various agreements or "social compacts". However, the import substitution strategy at the federal level and the local communist party elites' success in making investment decisions led to major inefficiencies (Uvalić 1992). Together with the oil shocks these changes led to higher foreign debt than a debt crisis in the early 1980s. The next two decades until the country's breakup were the years of stagnation (Aldcroft - Morewood 1995; Uvalić 2018).

\subsection{Yugoslavia and its federal units - growth and divergence}

Let us look at some of the basic facts of Yugoslav development, focussing on the Republics and Autonomous Provinces (Kosovo and Metohija and Vojvodina, both within Serbia) out of which seven internationally recognised independent states emerged (Slovenia, Croatia, Bosnia and Herzegovina, Montenegro, Macedonia, Serbia, and Kosovo - the last being recognised by many states but not by Serbia). A methodological note: In order to make relevant comparisons we used Social Product (SP) as defined by the Yugoslav Federal Statistical Office, as long as it existed. SP conceptually approximates GDP. However, SP was calculated only for the productive sector and excluded services such as government administration, defence, culture, education, healthcare, housing, and financial services. Eventually, some of these services were incorporated into SP, but there was never any adjustment of previously published data. Price distortions due to assigning high industrial prices in the initial period also played a role in inflating national accounts. So, this paper uses the official statistics, as generally illustrative if not completely accurate by the 
Western standards, to describe the broad development picture of former Yugoslavia as compared to the new states that sprang from its federal units.

The first fact is that Yugoslavia, as a whole, had a high average growth rate. During the 19471990 period, the $4.5 \%$ average growth rate led to an almost sevenfold increase in this national account aggregate (6.8). The per capita growth rate was 3.5\%. Furthermore, all the federal units experienced high growth (Miljković - Nikolić 1996, Appendix Table 1A.). Given the hardships of the first post-war years and the impact of the break with the Soviet bloc, average growth rates in all federal units are significantly higher for the 1952-1989 period, bringing the overall growth rate to $5.11 \%$ for Yugoslavia as a whole. Various adjustments that take into account price distortions (Kukić 2017) still give high average growth rates for the period as a whole. With ratios of adjusted-to-official-data growth rates varying between 0.90 and 0.99 for the federal units, the growth rate for all of Yugoslavia was $4.75 \%$ during the observed period. A World Bank study of long-term development puts the GDP per capita growth rate of Yugoslavia over the 1950-1975 period at 4.7\% (Morawetz 1977: 14). The two main growth characteristics of this period fit the general post-war development pattern: Industrialisation and urbanisation led to deep structural changes in the economy, with diminishing agriculture in aggregate economic activity leading to rapid urbanisation. The needs of industry also led to a rise in educational enrolment and a more qualified workforce.

On average, the high growth rates led to per capita income convergence with the developed countries. Between 1951 and 1990, GDP per capita (in 1990 GK international dollars) rose from 28 to $37 \%$ of the average per capita GDP of 12 most prosperous European nations. ${ }^{1}$ Using the same criteria, in 1952 Yugoslavia was more prosperous than Albania and Romania but lagged behind other Eastern European countries. By 1990, it had overtaken Bulgaria and Poland and had significantly closed the gaps with Hungary and Czechoslovakia, going from $54 \%$ to $87 \%$ of Hungary's and from $41 \%$ to $66 \%$ of Czechoslovakia's per capita GDP. These figures show significant convergence, given that in the immediate aftermath of the WWII, Yugoslavia was one of the poorest countries in Europe. Thus, all in all, Yugoslavia, despite its aforementioned deficiencies, was a huge success. However, there was a large difference between the per capita GDP of the Republics and of the Autonomous Provinces. Even though all the federal units experienced high growth rates in the post-war period, there was no convergence of GDP per capita between the federal units. The proclaimed political goal of narrowing the GDP per capita gap between the federal units, which was backed up by active policies, was not achieved. Instead, the differences widened.

The policies aimed at mitigating these differences were implemented in different ways and went through different phases. The first phase coincided with the Soviet-style central planning period that lasted from 1945 to 1951, when the disputes between the federal units in Yugoslavia were negotiated and resolved at the federal level. After central planning was ended the Yugoslav federation maintained control through the General Investment Fund, which was created in 1954 and allocated resources to the most profitable enterprises or to the investments that had political priority. The reform of 1965 ended the General Investment Fund and turned the resources over to the commercial banks. The backlash against the banks created the "contractual economy" and

\footnotetext{
${ }^{1}$ Calculations based on data from the Maddison project, available at www.rug.nl/ggdc/historicaldevelopment/maddison/. Twelve EU countries are the UK, France, Germany, Italy (North only), Austria, Belgium, Netherlands, Denmark, Finland, Sweden, Norway, and Switzerland, as presented in the Maddison project database of 2013, 01 version.
} 
25000

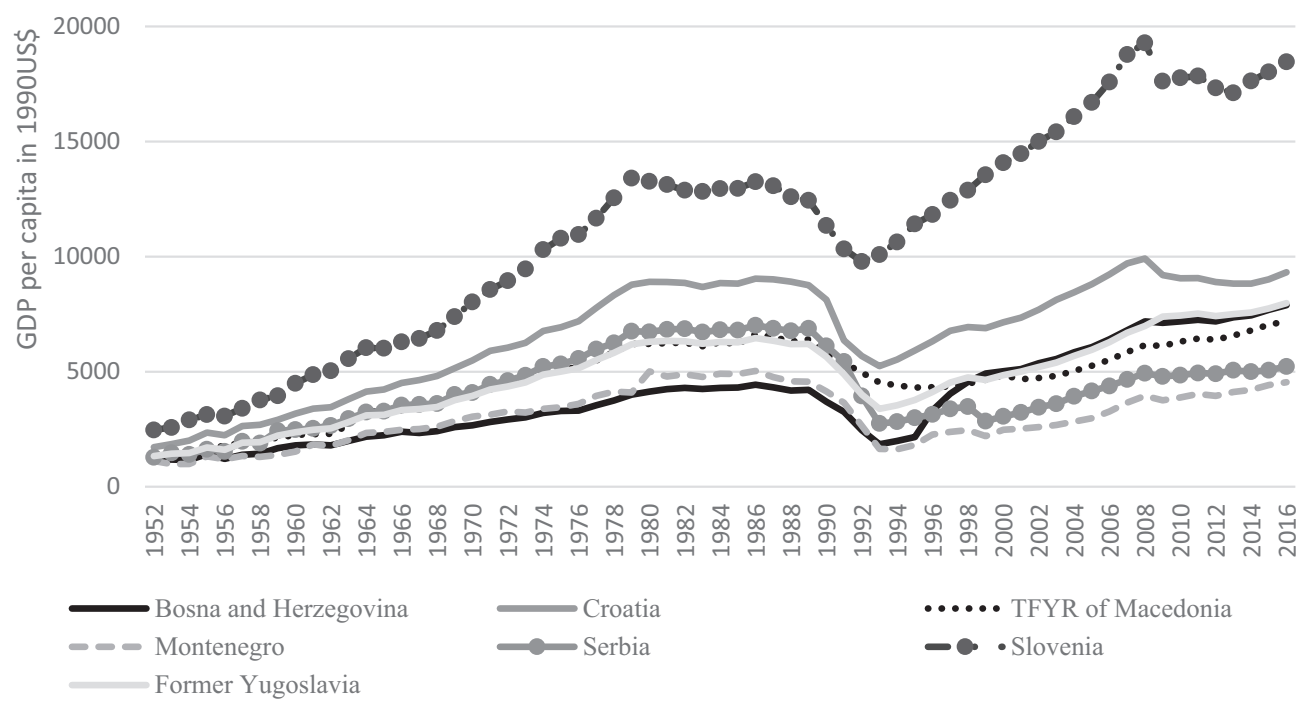

Source: Authors' calculation.

Figure 1. GDP per capita for Yugoslavia and the Republics in 1990 GK international dollars from 1952 to 2016

Source: Maddison project, available at https://www.rug.nl/ggdc/historicaldevelopment/maddison/ releases/maddison-project-database-2018

led to autarkic federal-unit import-substitution development strategies that resulted in stagnation (Milanovic 1987). Nevertheless, the policy of aiding the less developed regions was continued through the Federal Fund for the Accelerated Development of the Less Developed Republics (LDRs). This Fund drew its resources from the self-managed enterprises of the more developed regions (MDRs) by a quasi-tax of $1.9 \%$ of SP. The funds were used for investment on easy credit terms. In spite of all these policies, the divergence continued to grow, showing that in the institutional economic system of Yugoslavia they were ineffective.

The divergence was recognised by the official statistics and can be observed through a comparison of SP/head among the federal units with that in Yugoslavia as a whole, and with Slovenia as its most prosperous federal unit. (The official comparisons are provided in Table 2A in the Appendix.) The more prosperous regions (Slovenia, Croatia, Vojvodina) grew much faster, widening the gap with the poorer regions. The same conclusion is reached when observing data on per capita GDP in GK 1990 international dollars for the federal units over the 1952-2016 period. The data is presented in Figure 1. It is apparent that there was a continuous divergence and a general period of stagnation in the 1980s that added to the political tensions that led to the breakup of the country. GDP per capita fell as a result of the civil war and breakup 
of the country, the effect on the new states depending on the length of their involvement in the armed conflict. By the year 2000, all the new states were once again on a growth path, which ended with the financial crisis of 2008.

One of the questions this paper addresses concerns the speed of convergence of the new states' per capita GDP to the levels close to those of the more developed European countries. Using the same source for GDP per capita in GK 1990 dollars, we calculate and compare the levels of convergence to the levels of 12 most-developed European countries reached in 1990 and 2010 by the new states of former Yugoslavia. The data shows that by the year 2010, 20 years after the breakup of Yugoslavia, only two new states, Slovenia and Montenegro, had reached a higher level of convergence than in 1990, the year of the breakup. The rest had all experienced a drop in their level of convergence, some significantly. Given that since 2010 growth in the region has been volatile and sluggish, there is no reason to believe that there has been a significant change since then. The levels of convergence are presented in Table 1.

The generally lower levels of convergence in 2010 can be attributed to the economic disaster of the 1990s as a result of war and the breakup, as well as the drop-in economic activity due to the outbreak of the financial crisis in 2008.

Convergence in economics is also known as the catch-up effect and originates in the neoclassical growth model. One important finding of the model is that, ceteris paribus, per capita income tends to grow faster in poorer than in wealthier economies. As a result, all economies should eventually converge in terms of per capita income.

The assumption of the diminishing return in the neo-classical theory asserts that poor economies tend to grow faster than rich ones. Based on this, then the following should apply: the coefficient of variation for GDP per capita will slowly decrease and there will be an inverse relationship between the rate of economic growth for GDP per capita and the initial level of GDP per capita. However, the work of Sala-i-Martin (1996) suggested that different relationships may occur between these two types of convergence, and that beta convergence is a necessary but not sufficient condition for the sigma convergence process.

Table 1. Levels of convergence GDP per capita in 1990 GK international dollars of the former Yugoslavian states to the GDP per capita of 12 most prosperous European countries, \%

\begin{tabular}{|l|c|c|}
\hline State/year & 1990 & $\mathbf{2 0 1 0}$ \\
\hline Slovenia & 75 & 80 \\
\hline Croatia & 52 & 45 \\
\hline Bosnia and Herzegovina & 25 & 24 \\
\hline Serbia proper plus Vojvodina & 40 & 34 \\
\hline Macedonia & 39 & 28 \\
\hline Montenegro & 27 & 34 \\
\hline Kosovo & 9 & NA \\
\hline
\end{tabular}

Note: Authors' calculations based on Maddison database.

https://www.rug.nl/ggdc/historicaldevelopment/maddison/releases/maddison-project-database-2018. 


\section{CONVERGENCE AND THE NEW STATES OF FORMER YUGOSLAVIA}

At the end of the first decade of postcommunist transition, evidence on the convergence of the transition countries was still sparse. The general belief that after implementing the necessary transition reforms the transition countries would converge with the GDP per capita levels of the EU member states began to be questioned. Different initial conditions had to be taken into account, thus dividing the countries that were on the path to the EU accession (at that point in time) from other transition economies. A broad study (Rapacki - Prochniak 2009) that looks into the convergence among 27 transition countries over the period of 1990-2005 shows that these should be divided into subgroups. The study finds that convergence was unambiguously present in the group of the CEE countries, in both the group of 8 or 10 countries (adding Bulgaria and Romania); i.e., those countries that were on a sure path to full EU membership. The results for the CIS show no clear relationship in terms of convergence. For the Central and South-eastern European (CSEE) countries (former Yugoslav states less Slovenia plus Albania, Bulgaria, and Romania), the study finds $\beta$ (beta) convergence, but the results are far from robust. In other words, observing the New EU Member States (NMS) as a separate group remains fully justified. These countries have had to undergo determined market reforms. After joining the EU, they have become institutionally unified as opposed to others, who are either lagging behind in the accession process or are on their own "independent" transition trajectories. Even so, convergence appears to be a difficult and ambitious endeavour (Brzeski - Colombatto 1999) for the larger countries in this group.

A study that limits itself to the NMS that joined the EU as full members in 2004 (Vojinovic et al. 2010) finds that there was convergence at least within the observed time frame (1992-2006). Another study that tests convergence using the 1993-2007 period (Czasonis - Quinn 2012) also finds convergence between the CEE-10 and the older member states, but attributes this to the initial reforms of the EU accession process rather than to the membership itself, which seems to have no effect. It should be pointed out that these two studies do not include the years after the 2008 financial crisis. A broad study by Stanišić (2012) tries to make up for this inadequacy by exploring convergence between the "old member states" of the EU (EU-15) and NMS from CEE10 , as well as within the two groups of countries, during the 1993-2010 period. The chosen period includes some of the effects of the financial crisis, thus being more complete by including business cycle downturns. The results show the presence of convergence among the EU member states (EU-25) and among the CEE-10, and some divergence among the EU-15. This leads to the conclusion that there was a catching-up process. However, the crisis has reversed these results, with divergence manifesting itself among the CEE-10 and convergence among the EU-15. The explanation of the divergence in the CEE-10 is that the recession that followed the financial crisis led to a fall in foreign direct investment and foreign trade, both of which were generators of growth in these countries, thus exposing different vulnerabilities within this group that caused the divergence. The recurring conclusion that the EU accession process is crucial to the reforms that lead to growth and convergence is also reiterated in some country-specific studies, which point out that the reform impulse is usually lost after the accession to the EU, with other long-term institutional and historical factors becoming dominant (Csaba 2011).

The states of former Yugoslavia are usually incorporated into the slightly broader category of the Western Balkan States (WBS, which excludes Slovenia and adds Albania to the other exfederal units of Yugoslavia) or the South Eastern Europe region. Others have included them in 
the Balkans. The results of the studies are generally not very encouraging in terms of convergence. A study that tests convergence of the Balkan countries to the EU-15 before the expansion of 2004 and later (Tsanana et al. 2012) finds that only Slovenia and Greece were converging. Studies by the International Monetary Fund economists that assess the convergence hypothesis (Murgasova et al. 2015) find that the convergence to the European levels of GDP per capita is present in the WBS, but that it is slower than that of the NMS. On the other hand, Stanišic (2016) finds that the WBS stopped converging to the NMS after the financial crisis. The most recent research on the WBS countries (Siljak - Nagy 2018) confirms that these countries underwent a convergence process with the EU countries during the 2004-2008 period, but that the financial crisis during the 2008-2013 period slowed this process considerably. Nevertheless, convergence is confirmed for the $2004-2013$ period, as a whole.

The focus of this research is the convergence of development levels between the states of former Yugoslavia, which to our knowledge has not been explored in the literature. Although from the very beginning, development levels in Yugoslavia were very heterogeneous, all of the states that emerged from its breakup have two things in common. The first is a prolonged period of very high growth rates followed by a period of stagnation. The second is that all of them shared the same socialist market system in the decades before the breakup. This allows controlling for the effects of economic system on performance.

\section{THE HUMAN DEVELOPMENT INDEX AND CONVERGENCE}

As income gives an incomplete picture of the living conditions in different countries, the United Nations Development Programme (UNDP) constructed the HDI, which has been used annually to measure well-being since 1990. The HDI provides a more comprehensive measure of wellbeing by including life expectancy and education in addition to income as relevant dimensions of human development. We therefore chose to use the HDI to test for the presence of convergence in the development of the new states.

The HDI is an aggregate index that observes specific indicators as measures of achievement in the key dimensions of human existence: a long and healthy life, acquiring knowledge, and having a decent standard of living. The HDI is the geometric mean of normalised indicators: life expectancy at birth, expected years of schooling, mean years of schooling, and GNI per capita $(\mathrm{PPP} \$)^{2}$

Since the neoclassical concept of the convergence is based on the Solow growth model and its argument of diminishing returns, when switching from GDP per capita as an indicator it is important to ensure that the nature of the new indicator also embodies this concept. This is the case with the HDI, since one of the main components is income as expressed by GNI per capita. This also holds true for the education and life expectancy components: As the level of investment in health and education increases the returns on these investments will start to show signs of diminishing returns too. The largest effect of investment in these areas is to be expected in those countries that are at the lower end of the level of education and quality of health

\footnotetext{
${ }^{2}$ During the three decades since its inception the HDI has attracted a fair share of criticism regarding the weights and caps on its individual components and for its omission of important indicators such as pollution, income and gender inequality, human rights, etc.
} 
measurements. In order to register significant improvement in these indicators, countries that have already achieved higher school enrolment rates or life expectancy would have to switch to more expensive types of investment in these areas. For example, for the educational dimension this could require investment that would broaden college enrolment. In the area of increasing life expectancy it could mean obligatory screening processes or introducing some type of free national health care program.

Using HDI as a development indicator, Konya - Guisan (2008) confirmed the presence of $\beta$ and $\sigma$ convergence between the countries that were part of the EU before the 2004 enlargement and for the EU-25 in the 1975-2004 period. Bucur - Stangaciu (2015) obtained similar results when testing the hypothesis of real $\sigma$ and $\beta$ convergence of HDI levels between the EU member states in the 1995-2015 period. They discovered a relatively strong process of $\sigma$ convergence for this period but a slower $\beta$ convergence of the HDI in comparison to the results of GDP per capita convergence. The components that constitute the HDI can also be regarded as sources of growth straightforwardly positing that health and education will directly lead to enhanced productivity and increased competitiveness. Another article tested this panel data analysis and came to the conclusion that a rise in the HDI led to increased competitiveness (Talmaciu - Cismas 2016).

\subsection{Choice of period}

When comparing the new states that emerged from Yugoslavia, the first methodological question that needs to be addressed is the choice of time period. This is directly related to the wars that led to the breakup. As the various conflicts had different dynamics with different consequences, making comparisons using the period that includes the 1990s is problematic. While Slovenia and Macedonia exited Yugoslavia without a prolonged armed conflict and with no serious destruction, the rest were embroiled in wars with different consequences. The 1992 UN sanctions against what was then still called the Federal Republic of Yugoslavia (consisting of only Serbia and Montenegro) were not completely revoked until the downfall of Milošević in late 2000, and they had a detrimental effect on the economy and social fabric. Furthermore, these conflicts ended at different points in time. The NATO bombing of Yugoslavia in 1999 and the armistice that followed marked the end of the wars. There have been different estimates of the devastation resulting from the wars of the breakup, which will not be explicitly dealt with here but should be kept in mind as historical background. For all of these reasons, we have decided to exclude the period of the 1990s.

In order to skip the reconstruction period in the states that were affected by war, a period in which growth rates were usually high, we chose the 2004-2017 period to analyse convergence. This gives us 84 observation points and limits the scope of regression that can be performed with a high level of significance. Therefore, we only tested the hypothesis of absolute convergence between the states of former Yugoslavia and did not include multiple regressions with typical control variables (e.g., FDI, trade openness, quality of governance, public spending, natural resources, etc.). In order to exclude effects of the change in HDI calculation methodology that was introduced in 2010, we recalculated the HDI values using the new methodology for the pre2010 period. Data on the individual HDI indicators (life expectancy at birth, expected years of schooling, mean years of schooling, GNI per capita PPP in \$) were obtained from the UNDP human development database. ${ }^{3}$

${ }^{3}$ http://hdr.undp.org/en/data. 
The fact that Slovenia became an EU member in 2004 makes it unique in the sample, as in the observed period it had reformed the most and had access to the EU funds on a much larger scale than other countries.

\subsection{Methodology}

We use panel data analysis that makes it possible to test convergence using both cross-section and time series data; cross-section data was originally the standard way of testing the convergence hypothesis. As mentioned, the presence of convergence can be discussed in terms of $\beta$ and $\sigma$ convergence, where the former is only a precondition for the later. When testing $\beta$ convergence there are two dominant approaches. The first is based on extending the cross-sectional approach to the panel data model. This creates a dynamic panel model in which the value of the coefficient next to the lagged dependent variable signals if there is convergence or divergence between the countries in the sample. The second approach in testing $\beta$ convergence is based on unit root procedures in the panel data analysis. The idea behind this method is that the convergence process is present if the gaps from the benchmark values (most often the crosssectional average of the observed variable in each year) are stationary in stochastic terms. This way different panel unit root tests can be implemented to examine if the transformed data is stationary, thus verifying the convergence hypothesis. In determining the presence or absence of convergence in levels of the HDI between the former Yugoslavia states we use both approaches to test $\beta$ convergence.

When checking the presence of $\beta$ convergence a simple dynamic panel model can be used, with the only explanatory variable the lag in HDI level. Due to a characteristic of the panel data model, unobservable effects for a particular country can be incorporated through individual effects (fixed or stochastic) and/or effects of a time period, defined as:

$$
\ln H D I_{i t}=\beta \ln H D I_{i(t-1)}+a_{i}+a_{t}+\varepsilon_{i t}
$$

where $H D I_{i t}$ refers to the level of $H D I$ for the $i$-th country $(i=1,2, \ldots, N)$ in the $t$-th year $(t=1$, $2, \ldots, T) ; a_{i}$ represents individual effects for each country fixed in time, $a_{t}$ represents time effects common to all countries; and $\varepsilon_{i t}$ is a random term. For $\beta<1$, the presence of convergence is confirmed and the speed of convergence denoted by $\theta$ can be calculated from the formula

$$
\beta=-\frac{1-e^{-\theta T}}{T}+1
$$

where $T$ represents the number of years in which the speed rate is calculated.

For the estimation of parameter $\beta$, we first used the OLS estimator as a benchmark. Although OLS can be used to estimate models with a lagged dependent variable, this is a potentially dangerous strategy because of possible bias in the coefficient estimates. Achen (2000) applies this argument even when a lagged dependent variable is theoretically appropriate, as the presence of residual autocorrelation can lead to biased coefficient estimates. Our solution to the potential presence of residual autocorrelation is to use the generalised method of moments (GMMs) estimator. The estimation method is presented in Roodman (2009) and shows the advantages of using the GMM system instead of difference GMM when dealing with the dynamic panel models.

The estimation quality based on these instruments was checked by an additional ArellanoBond test for autocorrelation in the first and second order and the Sargan/Hansen test of over- 
Table 2. OLS and system GMM estimation of beta convergence in HDI for the former Yugoslavian states, 2004-2017

\begin{tabular}{|c|c|c|}
\hline & OLS & sys-GMM \\
\hline $\operatorname{lnHDI} t_{t-1}$ & $\begin{array}{c}0.9727611^{* * *} \\
(0.008004)\end{array}$ & $0.9835266 * * *(0.0383068)$ \\
\hline const. & $\begin{array}{l}-0.0009454 \\
(0.0020654)\end{array}$ & $0.0017015(0.0092248)$ \\
\hline Number of observations & 78 & 78 \\
\hline Number of groups & 6 & 6 \\
\hline$F(1,76)$ & $14770.42 * * *$ & \\
\hline Adj $R$-squared & 0.9948 & \\
\hline Speed of convergence & & 1.67 \\
\hline Half-life time & & 42 \\
\hline $\begin{array}{l}\text { Arrelano-Bond test for } A R(1) \text { in first } \\
\text { differences }\end{array}$ & & $z=-2.69 \operatorname{Pr}>z=0.039$ \\
\hline $\begin{array}{l}\text { Arrelano-Bond test for } A R(2) \text { in first } \\
\text { differences }\end{array}$ & & $z=-1.10 \operatorname{Pr}>z=0.205$ \\
\hline $\begin{array}{l}\text { Sargan test of overidentification } \\
\text { restrictions }\end{array}$ & & $\begin{array}{c}\text { chi2 }(19)=25.40 \text { Prob }> \\
\text { chi2 }=0.148\end{array}$ \\
\hline $\begin{array}{l}\text { Hansen test of overidentification } \\
\text { restriction }\end{array}$ & & $\begin{array}{c}\text { chi2 }(19)=5.20 \text { Prob }> \\
\text { cix2 }=0.999\end{array}$ \\
\hline Sargan test excluding group & & $\begin{array}{c}\text { chi2 }(9)=5.20 \text { Prob }>\text { chi2 }= \\
0.816\end{array}$ \\
\hline Difference (null $\mathrm{H}=$ exogenous) & & $\begin{aligned} \operatorname{chi} 2(10)= & 0.0 \text { Prob }>\text { chi2 }= \\
& 1.000\end{aligned}$ \\
\hline
\end{tabular}

Source: Authors' calculation using Stata15.

Note: $* * *$ denote statistical significance at $1 \%$ level.

identification restrictions. Estimates of the parameter $\ln H D I_{\mathrm{t}-1}$ using a two-step procedure and robust standard errors, with an additional test of model adequacy, are presented in Table 2.

\subsection{Results}

Based on the estimates for the lagged variable, which is statistically significant and lower than 1 , we can confirm the presence of absolute convergence between former Yugoslav states in terms of HDI for both OLS and GMM estimators. Since OLS estimation with a lagged dependent variable can generate a biased coefficient estimate, we focus on the results from the GMM estimation. From the value of the $\beta$ parameter a convergence speed of $1.74 \%$ was calculated. This suggests it would take the former Yugoslav states around 42 years to reduce the gap in the level of HDI by half. 
Additional test statistics confirm the adequacy of the number of instruments, although extremely good $p$ values of the Hansen test could imply that we may have over-fitted the endogenous variables. Additional estimation in which only the sixth lag of the dependent variable was used as an instrument resulted in more realistic $p$ values of the Hansen test of overidentification (results in Table $3 \mathrm{~A}$ in the Appendix). The results from additional estimation confirm the convergence hypothesis with a slightly higher rate of convergence, with which the gap in development could be halved in a period of 22 years.

For an additional proof of the convergence process we tested the presence of a unit root in the panel data, based on the Evans - Karras (1996) model, which was explained and tested with several procedures by Guetat - Serrantito (2005). In order to obtain the data for the unit root test we transform the original data through the formula:

$$
h d i_{i t}=\left(H D I_{i t}-\overline{h d i_{t}}\right)
$$

where $H D I_{i t}$ is the $H D I$ for the $i$-th country $(i=1,2, \ldots, N)$ in the $t$-th year $(t=1,2, \ldots, T)$ and $\overline{h d i_{t}}$ represents the cross-economy average value of the HDI in period $t$. Like in the first approach, with this transformation we are testing the hypothesis of absolute $\beta$ convergence in which the new data represents a unique balanced growth path. If convergence is present, then the calculated series $h d i_{i t}$ is stationary for all panels; otherwise a unit root will be present in at least one panel. In addition to this transformation we tested the convergence hypothesis with a panel unit root test based on the formula:

$$
h d i_{i t}^{*}=\ln \left(\frac{H D I_{i t}}{\overline{h d i_{t}}}\right)
$$

Ozcan (2014) suggested this transformation and observed a convergence process between 18 EU countries that is both stochastic and deterministic. For the purpose of testing the presence of a unit root in the transform series of the HDI for the former Yugoslav states, we conduct three types of unit root test due to a difference in their assumptions - and thus effectiveness - due to the characteristics of the data. The test for the presence of unit roots (or stationarity) in panel datasets is based on the autoregressive model:

$$
y_{i t}=a_{i t}+\rho_{i}^{*} y_{i t-1}+\varepsilon_{i t}
$$

where $\varepsilon_{i t}$ is a mean-zero regression error term and $a_{i t}$ represents the deterministic part of the model; $a_{i t}$ may include panel-specific intercepts (fixed effects), a panel-specific time trend, or nothing. The first unit root test that we use is the Levin-Lin-Chu (LLC) test. It is based on a general framework that allows individual fixed effects, common effects, and different dynamics across different groups in the sample. A major limitation of the LLC test is the assumption that all panels have the same value of $\rho$. The Im-Pesaran-Shin (IPS) (2003) test relaxes the assumption of a common $\rho$ and instead allows each panel to have its own $\rho_{i}$. Besides allowing for heteroskedasticity, serial correlation and non-normality, this test also allows for heterogeneity of trends and of the lag coefficient under the alternative hypothesis of no unit root. In addition, we used the Fisher Augmented Dickey-Fuller unit root test. The null hypothesis for each test is that all panels contain a unit root. From the results presented in Table 3 (with a 5\% level of significance), based on the $p$ values in all three tests we can conclude that both $h d i_{i t}$ and $h d i_{i t}^{*}$ are stationary processes. 
Table 3. Unit root test statistic for $h d i_{i t}$ and $h d i^{*}{ }_{i t}, 2004-2017$

\begin{tabular}{|l|c|l|c|l|}
\hline & \multicolumn{2}{|c|}{ hdi $_{i t}$} & \multicolumn{2}{c|}{ hdi $_{\text {it }}^{*}$} \\
\hline Levin-Lin-Chu & Adjusted $t^{*}=-3.396$ & $P$-value $=0.000$ & Adjusted $t^{*}=-3.289$ & $P$-value $=0.001$ \\
\hline $\begin{array}{c}\text { Im-Pesaran- } \\
\text { Shin }\end{array}$ & $W$-t-bar $=-1.7427$ & $P$-value $=0.041$ & $W$-t-bar $=-1.987$ & $P$-value $=0.024$ \\
\hline Fisher ADF type & $Z=-1.826$ & $P$-value $=0.034$ & $Z=-2.092$ & $P$-value $=0.018$ \\
\hline
\end{tabular}

These results confirm the previous findings from the first approach concerning the convergence in HDI level between the states of former Yugoslavia. The presence of $\beta$ convergence does not necessarily mean that the difference in HDI levels between the countries is decreasing. This depends on whether the countries that were at a lower development level at the beginning of the observed period were experiencing significantly higher growth rates in the case for which we have $\beta$ convergence. If this trend continues long enough without a decrease in the growth rate, technically these countries can overtake the countries that were more developed at the beginning of the period. Although $\beta$ convergence was initially observed, in this case the process of $\sigma$ convergence is not present. Alternatively, it is possible that random shocks increase the difference between countries even though $\beta$ convergence is present in most of the observed period.

Despite the fact that this is not likely to be the case in our sample, the confirmation of $\sigma$ convergence would additionally verify the results of the $\beta$ convergence process, since it is a necessary but insufficient condition for $\sigma$ convergence. For the purpose of testing $\sigma$ convergence we use the rudimentary approach, which focuses on how the coefficient of variation for the group of countries changes throughout the period under observation. If its value increases we cannot conclude that $\sigma$ convergence is occurring for the sample of countries. In Figure 2 we present the data and trend of the coefficient of variation $(\mathrm{CV})$ for the states of former Yugoslavia. We find that, despite exceptions in the years 2010 and 2013, the overall trend is decreasing, which suggests that besides $\beta$ convergence there is also $\sigma$ convergence of HDI levels.

Additional statistics are presented in Table 4 which confirm that the negative trend-line coefficient is statistically significant, although with quite a small value of -0.0013 per year. This suggests that even though $\sigma$ convergence is present between the former Yugoslavia states, the rate of reduction of development differences is extremely slow.

Since the HDI is a composite index, observing the change in the separate dimensions of the index could shed light on which dimension is the main driver of the convergence process between the former Yugoslav states.

As shown in Figure 3, in the observed period the process of $\sigma$ convergence is present in two of three dimensions. The largest decrease in differences between the countries is in the dimension of education. Here, the only increase in disparity was recorded in years 2009 and 2010, coincidental with the global financial crisis. Examination of the individual data for this dimension shows that the education index for Bosnia and Herzegovina and Serbia dropped in one or both of these two years, while the other countries retained their position or even 


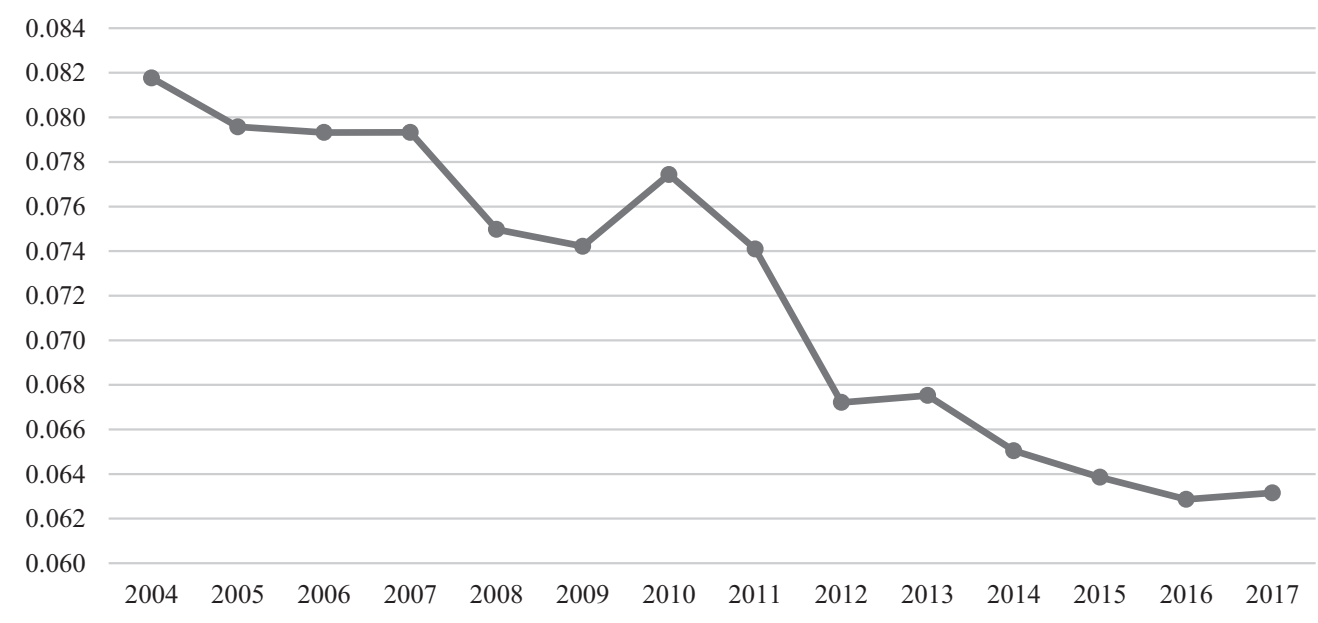

Source: Authors' calculation.

Figure 2. Coefficient of variation of HDI for the former Yugoslavian states, 2004-2017

continued to grow. Standard of living also contributed to the overall $\sigma$ convergence process of the HDI during the observed period, but at a much slower pace and with a slight divergence in the last observed year. As opposed to the previous two dimensions, health, the last dimension of the HDI, shows signs of $\sigma$ divergence in the 2004-2018 period, with a slow constant increase. Although all of the former Yugoslav countries show an improvement in this dimension, Slovenia records a much higher increase in life expectancy at birth than the other states. In this dimension, there is actually an increase in the difference between Slovenia and the rest of the former states of Yugoslavia, leading to an overall slow divergence.

Table 4. Coefficient of variation trend for the former Yugoslavian states, 2004-2017

\begin{tabular}{|c|c|c|c|c|c|c|}
\hline Source & SS & df & Ms & \multicolumn{3}{|c|}{$T=14$} \\
\hline Model & 0.000580 & 1 & 0.00058 & \multicolumn{3}{|c|}{$F(1,9)=149.25$} \\
\hline Residual & 0.000046 & 12 & 0.00000 & \multicolumn{3}{|c|}{ Prob $>F=0.0000$} \\
\hline Total & 0.000637 & 13 & & \multicolumn{3}{|c|}{$R$-squared $=0.9256$} \\
\hline & & & & \multicolumn{3}{|c|}{ Adj. $R$-squared $=0.9194$} \\
\hline cV & Coef. & Std. Err. & $t$ & $P>t$ & \multicolumn{2}{|c|}{ [95\% Conf. interval] } \\
\hline Trend & -0.001597 & 0.000131 & -12.2167 & 0.000 & -0.00188 & -0.00131 \\
\hline _cons & 0.084145 & 0.001113 & 75.6051 & 0.000 & 0.08172 & 0.08657 \\
\hline
\end{tabular}




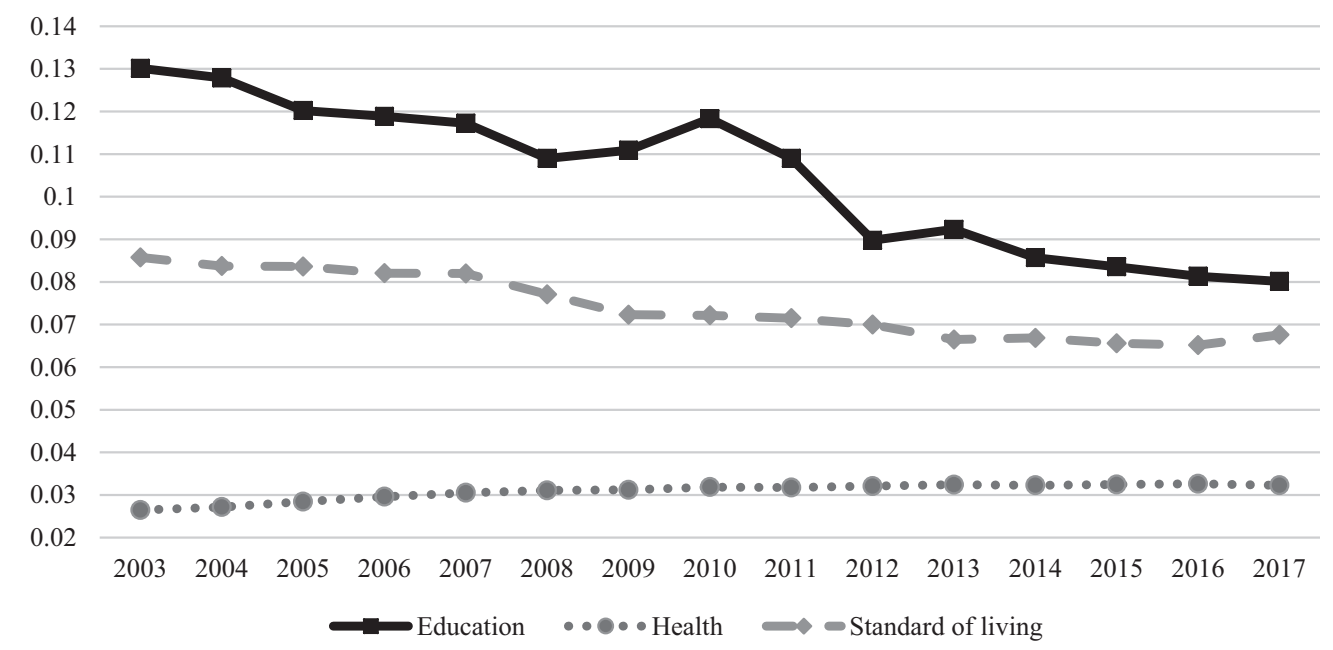

Source: Authors' calculation.

Figure 3. Coefficient of variation of HDI dimensions for the former Yugoslavian states, 2003-2017

\section{CONCLUSION}

In terms of HDI levels, the states of former Yugoslavia were experiencing both $\beta$ and $\sigma$ convergence. However, since the rate of this convergence is extremely slow the implication is that large shocks could easily reverse the trend. These findings have important policy implications. The most obvious is that this slow convergence process could be accelerated by the active EU policies. Although an open-door policy for the accession process of the Western Balkan countries was promised back in 2003 at the Thessaloniki summit, the only two countries that became members were: Slovenia and Croatia. If we discount Slovenia, which was already well down the road to accession with others in the "Big Bang" enlargement of 2004, that leaves only Croatia. The accession process has dragged on for many reasons, mostly political in nature. In the wake of the various crises in the EU, the renewal of commitment to the Western Balkan states at the Sophia summit in 2018 was somewhat restrained. Nevertheless, the accession process is continuing.

In order to ease the accession process to full EU membership, a process that requires difficult, long, and often painful reforms, boosting convergence among the states in the region would be helpful. However, the rules of the accession process are such that they appropriate larger funds to the NMS than to the candidate states. This is somewhat paradoxical, because the needs of the candidate states that are in the process of reform should logically be more encompassing and urgent than those who have become the new members. Recognising this, the EU initiated the Berlin Process for the Western Balkan states, with the aim of deepening and enhancing cooperation among them and pushing the "connectivity agenda,", mostly oriented to energy and transport. The hope is that cooperation will boost economic growth, thus leading to higher convergence. 
It should be remembered that the countries of the region were identified as the poorest in Europe even before the end of the WWII. The well-known article by Rosenstien-Rodan (1943), has initiated the Big Push model of economic development. Perhaps this idea should be rekindled. The continuing process of convergence is one of the cornerstones of EU legitimacy. It is difficult to conceive how the process of enlargement can succeed under the circumstances that do not make the convergence process sufficiently tangible and visible. It seems that only deeper EU engagement can achieve this.

\section{REFERENCES}

Achen, C. H. (2000): Why Lagged Dependent Variables Can Suppress the Explanatory Power of Other Independent Variables. In: Annual Meeting of the Political Methodology Section of the American Political Science Association, Los Angeles, July 20-22.

Aldcroft, D. - Morewood, S. (1995): Economic Change in Eastern Europe Since 1918. Aldershot Hants: Edward Elgar.

Bajt, A. (1988): Samoupravni oblik društvene svojine (The Self-Managed Form of Social Property). Zagreb: Globus.

Brzeski, A. - Colombatto, E. (1999): Can Eastern Europe Catch Up?. Post-Communist Economies, 11(1): 525.

Bucur, I. - Stangaciu, O. (2015): The European Union Convergence in Terms of Economic and Human Development. CES Working Papers, 7(2): 256-275.

Csaba, L. (2011): And the First Shall be the Last. Hungarian Studies, 25(2): 235-248.

Czasonis, M. - Quinn, M. (2012): Income Convergence in Europe: Catching up or Falling Behind?. Acta Oeconomica, 62(2): 183-204.

Estrin, S. (1983): Self-Management: Economic Theory and Yugoslav Practice, Cambridge: Cambridge University Press.

Evans, P. - Karras, G. (1996): Convergence Revisited. Journal of Monetary Economics, 37(2): 249-265.

Gill, I. - Raiser, M. (2012): Golden Growth: Restoring the Luster of the European Economic Model. Washington, DC. World Bank.

Gregory, P. - Stuart, R. (2014): The Global Economy and its Economic Systems. South-Western Cengage.

Guetat, I. - Serranito, F. (2005): Using Panel Unit Root Tests to Evaluate the Income Convergence Hypothesis in Middle East and North Africa Countries. Centre National de la Recherche Scientifique, Université Paris 1.

Horvat, B. (1982): The Political Economy of Socialism. Armonk. New York: M. E. Sharpe.

Konya, L. - Guisan, M. (2008): What does the Human Development Index Tell us about Convergence?. Applied Econometrics and International Development, 8(1): 19-40.

Kukić, L. (2017): Regional Development under Socialism: Evidence from Yugoslavia. Economic History Working Papers, No. 267/2017, LSE.

Lampe, J. (2000): Yugoslavia as History - Twice There was a Country. Cambridge: Cambridge University Press.

Matuszak, P. - Szarzec, K. (2019): The Scale and Financial Performance of State-Owned Enterprises in the CEE Region. Acta Oeconomica, 69(4): 549-570. 
Milanović, B. (1987): Patterns of Regional Growth in Yugoslavia 1952-83. Journal of Development Economics, 25(1): 1-19.

Miljković, D. - Nikolić, M. (1996): Razvoj Republika SFR Jugoslavije 1947-1990, Studije, analize, prikazi (The Development of the Republics of the Socialist Federal Republic of Yugoslavia, 1947-1990, Studies, Analysis and Reviews). Savezni zavod za statistiku (Federal Statistical Office), No. 132.

Morawetz, D. (1977): Twenty Five Years of Economic Development. Washington, DC: World Bank.

Murgasova, Z. - Ilahi, N. - Miniane, J. - Scott, A. - Vladkova-Hollar, I. (2015): The Western Balkans: 15 Years of Economic Transition. Washington, DC: IMF.

Ozcan, B. (2014): Does Income Converge among EU Member Countries Following the Post-War Period? Evidence from the PANKPSS Test. Romanian Journal of Economic Forecasting, 17(3): 22-38.

Palairet, M. (1997): The Balkan Economies 1800-1914 - Evolution without Development. Cambridge: Cambridge University Press.

Rapacki, R. - Prochniak, M. (2009): Real Beta and Sigma Convergence in 27 Transition Countries, 19902005. Post-Communist Economies, 21(3): 307-326.

Roodman, D. (2009): How to do Xtabond2: An introduction to Difference and System gmm in Stata. Stata Journal, 9(1): 86-136.

Rosenstien-Rodan, P. 1943. Problems of Industrialization of Eastern and South Eastern Europe. Economic Journal 53, 202-211.

Sala-i-Martin, X. X. (1996): Regional Cohesion: Evidence and Theories of Regional Growth and Convergence. European Economic Review, 40(6): 1325-1352.

Siljak, D. - Nagy, S. (2018): The Effects of the Crisis on the Convergence Process of the Western Balkan Countries towards the European Union. Society and Economy, 40(1): 105-124.

Stanišić, N. (2012): The Effects of the Economic Crisis on Income Convergence in the European Union. Acta Oeconomica, 62(2): 161-182.

Stanišić, N. (2016): Income Convergence in the Process of the Western Balkan States' Accession to the European Union. Economic Horizons, 18(1): 3-15.

Talmaciu, A. - Cismas, L. (2016): National Competitiveness through the Europe 2020 Strategy and Human Development Index in CEE Countries: A Panel Data Analysis. Timisoara Journal of Economics and Business, 9(2): 115-128.

Tsanana, E. - Katrakilidis, C. - Pantelidis, P. (2012): Balkan and EU-15: An Empirical Investigation of Income Convergence. In: Karasavvoglou, A. - Polychronidou, P. (eds): Balkan and Eastern European Countries in the Midst of the Global Economic Crisis (Contributions to Economics). Berlin Heidelberg: Springer-Verlag.

Vanek, J. (1970): The General Theory of Labour-Managed Market Economies. Ithaca, NY: Cornell University Press.

Vojinovic, B. - Oplotnik, Z. - Prochniak, M. (2010): EU Enlargement and Real Economic Convergence. Post-Communist Economies, 22(3): 303-322.

Uvalić, M. (1992): Investment and Property Rights in Yugoslavia - The Long Transition to a Market Economy. Cambridge: Cambridge University Press.

Uvalić, M. (2018): The Rise and Fall of Market Socialism in Yugoslavia. Berlin: DOC Research Institute. Ward, B. (1958): The Firm in Illyria: Market Syndicalism. American Economic Review, 48(4): 566-589. 


\section{APPENDIX}

Table 1A. Growth rates of social product total and per capita for Yugoslavia and its Republics and autonomous provinces

\begin{tabular}{|l|c|c|}
\hline $\begin{array}{l}\text { Republics and autonomous } \\
\text { provinces }\end{array}$ & $\begin{array}{c}\text { Growth rates of social product } \\
\text { 1947-1990 (1972 prices) total }\end{array}$ & $\begin{array}{c}\text { Growth rates of social product per } \\
\text { capita 1947-1990 (1972 prices) }\end{array}$ \\
\hline Yugoslavia & 4.5 & 3.5 \\
\hline Bosnia-Herzegovina & 4.3 & 2.9 \\
\hline Montenegro & 4.2 & 2.9 \\
\hline Croatia & 4.5 & 4.0 \\
\hline Macedonia & 4.8 & 3.3 \\
\hline Slovenia & 4.8 & 4.0 \\
\hline Serbia total & 4.5 & 3.4 \\
\hline Serbia central & 4.5 & 3.6 \\
\hline Serbia-Vojvodina & 4.5 & 4.0 \\
\hline Serbia-Kosovo & 4.0 & 1.6 \\
\hline
\end{tabular}

Source: Miljković - Nikolić (1996).

Table 2A. Comparison of social product per capita for Yugoslavia and its Republics and autonomous provinces in relation to Yugoslavia as a whole and to Slovenia in 1947 and 1990, \%

\begin{tabular}{|l|c|c|c|c|}
\hline \multirow{2}{*}{$\begin{array}{l}\text { Federal units } \\
\text { Social product per capita }\end{array}$} & Year 1947 & \multicolumn{2}{|c|}{ Year 1990 } & \multicolumn{2}{c|}{ Year 1947 } & Year 1990 \\
\cline { 2 - 5 } & \multicolumn{2}{|c|}{ Yugoslavia $=\mathbf{1 0 0}$} & \multicolumn{2}{c|}{ Slovenia = 100 } \\
\hline Yugoslavia & 100 & 100 & 61 & 50 \\
\hline Bosnia - Herzegovina & 86 & 67 & 53 & 33 \\
\hline Montenegro & 94 & 72 & 58 & 36 \\
\hline Croatia & 104 & 127 & 64 & 63 \\
\hline Macedonia & 70 & 64 & 43 & 32 \\
\hline Slovenia & 163 & 201 & 100 & 100 \\
\hline Serbia total & 95 & 92 & 58 & 46 \\
\hline Serbia central & 100 & 105 & 61 & 52 \\
\hline Serbia - Vojvodina & 100 & 122 & 58 & 61 \\
\hline Serbia - Kosovo & 49 & 22 & 30 & 11 \\
\hline
\end{tabular}

Source: Miljković - Nikolić (1996). 
Table 3A. System GMM estimation of beta convergence in HDI for the former Yugoslavian states using only seventh lag of dependent variable as instrument, 2004-2017

\begin{tabular}{|c|c|c|c|c|c|c|}
\hline \multicolumn{2}{|c|}{ Number of instruments $=13$} & & & \multicolumn{3}{|c|}{ Number of observations $=78$} \\
\hline \multicolumn{2}{|l|}{ Wald chi2 $=10208.71$} & & & \multicolumn{3}{|c|}{ Number of groups $=6$} \\
\hline \multicolumn{2}{|l|}{ Prob $>$ chi2 $=0.000$} & & & & & \\
\hline & & \multicolumn{2}{|c|}{ Corrected } & & & \\
\hline $\mathrm{X}$ & Coef. & Std. Err. & z & $P>|z|$ & {$[95 \%$ CoI } & Interval] \\
\hline \multicolumn{7}{|l|}{$x$} \\
\hline L1. & 0.96016 & 0.00950 & 101.04 & 0.000 & 0.94152 & 0.97877 \\
\hline _cons & -0.00408 & 0.00252 & -1.62 & 0.105 & -0.00901 & 0.00008 \\
\hline Speed of convergence & 4.1 & & & & & \\
\hline Half life time & 17 & & & & & \\
\hline \multicolumn{7}{|c|}{ Arrelano-Bond test for $\mathrm{AR}(1)$ in first differences: $z=-1.94 \operatorname{Pr}>\mathrm{z}=0.052$} \\
\hline \multicolumn{7}{|c|}{ Arrelano-Bond test for $\mathrm{AR}(2)$ in first differences: $z=-1.23 \mathrm{Pr}>\mathrm{z}=0.220$} \\
\hline \multicolumn{7}{|c|}{ Sargan test of overidentification restrictions: $\operatorname{chi} 2(7)=8.57$ Prob $>$ chi2 $=0.285$} \\
\hline \multicolumn{7}{|c|}{ Hansen test of overidentification restrictions: chi2 $(7)=5.53$ Prob $>$ chi2 $=0.596$} \\
\hline \multicolumn{7}{|c|}{ Hansen test excluding group: chi2 $(3)=4.79$ Prob $>$ chi2 $=0.188$} \\
\hline \multicolumn{7}{|c|}{ Difference (null $\mathrm{H}=$ exogenous): chi2 $(4)=0.74$ Prob $>$ chi2 $=0.946$} \\
\hline
\end{tabular}

